\title{
O ESTADO E O EXTERMÍNIO: AS FONTES PARLAMENTARES E JUDICIAIS SOBRE A “OPERAÇÃO MATA-MENDIGOS” (GUANABARA, 1962-1963)
}

\author{
THE STATE AND THE SLAUGHTER: THE PARLIAMENTARY AND \\ JUDICIAL SOURCES ON THE “OPERATION KILLER OF \\ BEGGARS” (GUANABARA, 1962-1963)
}

Mariana Dias Antonio ${ }^{1}$

RESUMO: Um conjunto de crimes praticados por agentes do Serviço de Repressão à Mendicância do estado da Guanabara veio à tona no início de 1963, resultando na assim chamada "Operação mata-mendigos" ou "Chacina do rio da Guarda". O caso é usualmente abordado de maneira tangencial e a partir de fontes de imprensa ou relatos de jornalistas e políticos. Visando complementar as narrativas sobre o caso e esclarecer alguns discursos infundados, analisamos dois documentos usualmente negligenciados e produzidos pelo Estado: o parecer da Comissão Parlamentar de Inquérito sobre os crimes e a sentença de pronúncia contra os implicados.

PALAVRAS-CHAVE: Operação mata-mendigos; Chacina do rio da Guarda; Comissão Parlamentar de Inquérito; Sentença de pronúncia; Guanabara.

ABSTRACT: A set of crimes committed by agents of the Service for the Repression of Begging from the state of Guanabara surfaced in early 1963, resulting in the so-called "Operation killer of beggars" or "Rio da Guarda massacre". The case is usually approached tangentially and from press sources or accounts from journalists and politicians. Aiming to complement the narratives about the case and elucidade some unfounded discourses, we analyzed two documents usually neglected and produced by the State: the

\footnotetext{
* Este artigo é fruto da pesquisa de doutorado intitulada “A 'Operação Mata-Mendigos' na Guanabara: representações e apropriações no jornal Ultima Hora, no Poder Legislativo, no Poder Judiciário, no teatro e no cinema", defendida em agosto de 2021 no Programa de PósGraduação em História da Universidade Federal do Paraná, sob orientação do Prof. Dr. Pedro Plaza Pinto e coorientação da Profa. Dra. Rosane Kaminski. O presente trabalho foi realizado com apoio da Coordenação de Aperfeiçoamento de Pessoal de Nível Superior - Brasil (CAPES) - Código de financiamento 001.

1 Doutora e mestra em História pela Universidade Federal do Paraná (UFPR). Licenciada em História pelo Centro Universitário Dr. Edmundo Ulson. Membro dos grupos de pesquisa "Arte, Memória e Narrativa" (AMENA/UFPR) e "Cinema, análise fílmica e experiência intelectual" (CineArte/UAM). Email: mariana.diasant@gmail.com.
} 
legislative opinion for the Parliamentary Commission of Inquiry on the crimes and the indictment sentence against the culprits.

KEYWORDS: Operation killer of beggars; Rio da Guarda massacre; Parliamentary Commission of Inquiry; Indictment sentence; Guanabara.

\section{Introdução}

Uma denúncia publicada pelo jornal carioca Ultima Hora, em janeiro de 1963, tornou público o extermínio de "mendigos"2 por policiais do Serviço de Repressão à Mendicância (SRM), vinculado ao Departamento Estadual de Segurança Pública (DESP) da Guanabara, estado criado em 21 de abril de 1960 com a transferência da capital nacional para Brasília e que compreendia o perímetro urbano da cidade do Rio de Janeiro. Olindina Alves Japiassu sobreviveu a uma tentativa de homicídio na ponte do rio da Guarda e denunciou as arbitrariedades à imprensa, o que criou certo estigma na gestão do então governador Carlos Lacerda (1960-1965). O episódio ficou conhecido como "Operação mata-mendigos", havendo a participação de sete indivíduos - entre policiais efetivos e emprestados para o SRM, seu chefe e motoristas - e um total de vinte vítimas, após confissão dos envolvidos.

As declarações de Olindina não inauguram o denuncismo do periódico contra a gestão de Carlos Lacerda, nem o aparecimento de corpos nos rios cariocas, tampouco as arbitrariedades cometidas pelo SRM contra "mendigos". Entretanto, estes elementos se unem a partir de seu relato, levando à constatação de certa amplitude, iteração e sistematicidade de crimes cometidos. O episódio ressurge no debate público com o longa-metragem Topografia de um desnudo (2009), de Teresa Aguiar, que prioriza fontes de imprensa e relatos de jornalistas para contar essa história em meio a uma trama ficcional.

Em recente sistematização de dezesseis livros que abordam a “Operação mata-mendigos" (ANTONIO, 2020), observam-se obras derivadas das memórias de jornalistas ou políticos que acompanharam o caso, além de

\footnotetext{
${ }^{2}$ Preservamos o termo nativo, cientes de que a condição de "mendigo" se difere da situação de rua por se originar no ordenamento jurídico, como indivíduo que incorre na antiga contravenção de mendicância. Trazemos todas as ocorrências do termo entre aspas, preservando a glosa do período e tendo em vista o estigma que ele carrega.
} 
resultados de pesquisas acadêmicas que também priorizam fontes de imprensa e relatos pessoais. Uma análise dos livros mais citados por outros da mesma amostra deixa evidente que biografias de Carlos Lacerda, então governador da Guanabara, e Samuel Wainer, fundador e diretor do jornal carioca Ultima Hora, são as fontes preferenciais de informações sobre o caso.

Expandindo-se a amostra do trabalho citado, outra recente biografia de Wainer (MONTEIRO, 2020) apresenta ao menos oito menções a livros que também citam o caso, persistindo problemas que vão além do viés de fontes, ao exemplo do mero tangenciamento do assunto a outras problemáticas mais amplas, como histórias de vida individuais, a história política e administrativa do Rio de Janeiro, a história da imprensa carioca ou narrativas amplas sobre violência policial e controle social. Entre teses e dissertações recentes com breves menções à "Operação mata-mendigos”, nota-se também a incorporação acrítica de informações do longa-metragem Topografia de um desnudo, o que evidencia a necessidade de se abordar o caso por um corpo distinto de fontes históricas.

Cumpre-nos esclarecer que alguns trabalhos pontuais já se empenharam em trazer maior variabilidade de fontes. Marly Silva da Mota (2001) se apropria dos autos da Comissão Parlamentar de Inquérito (CPI) que investigou o caso; Renata Martins de Freitas (2018) se apropria do acórdão da ação penal de Sandra Cavalcanti contra Miro Teixeira, julgada pelo Supremo Tribunal Federal (STF) em 1984, que sintetiza o que foi a "Operação matamendigos"; e Brodwyn Fischer (2008) se apropria do inquérito criminal conduzido pelo delegado Ariosto Fontana à época. Ainda assim, o tangenciamento do assunto a problemáticas mais amplas persiste. A carência de centralidade do episódio na historiografia evidentemente acarreta em certo prejuízo de informações, podendo-se apontar lacunas diversas sobre o agenciamento das práticas, sua amplitude, causas e consequências diretas e indiretas. Em movimento distinto, Mariana Dias Antonio (2019) oferece grande centralidade à "Operação mata-mendigos", mas o viés de fontes se enfatiza ao apresentar o caso prioritariamente a partir do jornal Ultima Hora. 
Constatados esses problemas, o presente artigo busca complementar as narrativas sobre o caso a partir de documentos sincrônicos produzidos pelo Poder Público. Analisamos o parecer do relator da CPI que investigou o caso, bem como o acórdão e a sentença de pronúncia contra os implicados, utilizando fontes de imprensa - sobretudo o jornal Última Hora, pioneiro nas denúncias apenas quando necessário para complementar algumas lacunas existentes.

Os autos da CPI que apurou o caso encontram-se disponíveis para consulta no Arquivo da Assembleia Legislativa do Rio de Janeiro (ALERJ), contando com mais de cinco mil páginas separadas em quatro volumes, das quais diversas se encontram degradadas ou ilegíveis. Por esse motivo, analisamos apenas do parecer do relator, deputado Paulo Duque, do Partido Republicano (PR). O parecer compõe as primeiras páginas dos autos e pode causar estranhamento, uma vez que em sua capa consta "II Parte: Deportação e matança de mendigos". O documento também não se encontra datado e assinado. Todavia, estes pontos de dúvida são facilmente sanados pelas fontes de imprensa, que nos informam sobre a entrega do relatório ao plenário em 18 de setembro de 1963 (ULTIMA HORA, 19/09/1963) e ao presidente da comissão em 5 ou 6 de novembro do mesmo ano (ULTIMA HORA, 06/11/1963). As fontes de imprensa também informam sobre a existência de duas etapas na primeira fase do inquérito: uma para apurar o episódio no Regimento de Cavalaria Caetano de Faria, quando o secretário de Segurança Pública, Gustavo Borges, impediu a entrada de parlamentares para interrogar os implicados; e outra retornando ao seu objeto central, a matança de "mendigos". A segunda fase do inquérito expande o escopo investigativo para outros estabelecimentos policiais da Guanabara, com ênfase para a Invernada de Olaria (Cf. ANTONIO, 2019, p.92-94).

Para além do parecer do inquérito parlamentar, que sumariza os resultados das investigações empreendidas pelo Poder Legislativo, também tivemos acesso às apurações realizadas pelo Poder Judiciário. O acórdão (segunda instância) e a sentença de pronúncia (primeira instância), acompanhada das matérias de fato e de direito sobre o caso, foram publicados 
no volume 212 da Revista Forense, referente ao último trimestre de 1965. A sentença fora pronunciada pelo juiz Roberto Talavera Bruce em 18 de julho de 1963 e apresentada aos implicados em 7 de agosto de 1963. (ÚLTIMA HORA, 08/10/1963). O julgamento foi confirmado em segunda instância no dia 3 de dezembro de 1964. Apesar de publicada em revista especializada, esta fonte permanece intocada por trabalhos acadêmicos. E ainda que o pronunciamento de sentença tenha natureza e propósito distintos do inquérito parlamentar, a confrontação destes documentos nos permite elucidar aspectos ainda nebulosos sobre o caso a partir de uma narrativa oficializada pelos poderes instituídos, evitando o supracitado viés de fontes.

Uma tentativa de compreensão ampla do caso: o inquérito parlamentar

O parecer do relator da CPI parte da edição do jornal Ultima Hora de 29 de agosto de 1962, quando o repórter Amado Ribeiro denunciou o despejo de "mendigos" para fora do estado da Guanabara. O relatório destaca que, inicialmente, "[a] notícia causou espanto e indignação na opinião pública; entretanto, veiculada que fora por jornal notoriamente contrário ao atual Governador do Estado, a reportagem fora recebida com certa reserva" (GUANABARA, 1963, p.1). Rememora-se o comentário do chefe de polícia, Newton Marques Cruz, em entrevista ao Ultima Hora em 31 de agosto de 1962, quando disse não acreditar nas denúncias, mas apuraria as responsabilidades dos implicados caso fossem verdade. Mesmo negando as arbitrariedades, foi baixada a ordem de serviço $\mathrm{n}^{\circ}$ 64, assinada por Fernando Carvalho de Silva, chefe do Serviço de Transportes, permitindo que somente viaturas autorizadas pelo chefe de polícia cruzassem as barreiras do estado da Guanabara (GUANABARA, 1963, p.2-3).

Com as denúncias do jornal, o deputado Affonso Arinos de Melo Franco Filho, da União Democrática Nacional (UDN), enviou à Mesa Diretora da Assembleia Legislativa da Guanabara (ALEG) o requerimento $\mathrm{n}^{\circ} 367$, de 6 de setembro de 1962, solicitando esclarecimentos ao governador 
(GUANABARA, 1963, p.4). O requerimento seria relembrado e reproduzido integralmente pelo jornal Ultima Hora (17/04/1963), mas ficaria sem resposta.

As práticas de extermínio adquirem dimensão pública com a viagem denunciada pela sobrevivente Olindina Alves Japiassu, muito embora essa viesse a ser confessada pelos implicados como a quarta viagem para tais fins. No dia 17 de janeiro de 1963, uma viatura do SRM deixa suas dependências durante a noite com destino ignorado, ocupada por José Mota (guarda civil), Nilton Gonçalves da Silva (funcionário da Agência Nacional, emprestado ao SRM), Pedro Saturnino dos Santos (guarda noturno) e o motorista Mário Teixeira. No compartimento traseiro se encontravam seis "mendigos": Zuleica de tal, Eunice Marques Evangelista, Olindina Alves Japiassu, Geraldo Pereira, José de tal e Milton Rodrigues Barbosa.

No dia seguinte, foram recolhidos do rio da Guarda os cadáveres de Eunice Marques Evangelista e Milton Rodrigues Barbosa; em 19 de janeiro, o corpo de José de tal; em 22 de janeiro o corpo de Geraldo Pereira; e em 6 de fevereiro o corpo de Zuleica de tal. Olindina Alves Japiassu sobrevivera, apesar de ferida por ter sido arremessada da ponte que liga o município fluminense de Itaguaí ao estado da Guanabara ${ }^{3}$. Com a descoberta do crime, o delegado Ariosto Fontana, do $36^{\circ} \mathrm{DP}$, tomou providências para deter seus autores (GUANABARA, 1963, p.6).

O pronunciamento de sentença também traz as viagens de deportação como elemento fundador das arbitrariedades, mas atenta que tais práticas já ocorriam antes da gestão de Alcino Pinto Nunes no SRM, em 1960, vindo a progredir para as viagens de extermínio. No entanto, conforme a matéria de fato sobre o caso, é possível que outras viagens com execuções - além das quatro confessadas - tenham ocorrido.

\footnotetext{
3 Diversos nomes aqui trazidos apresentam divergências com outras fontes (Cf. ANTONIO, 2019; 2020). A normalização dos nomes para as vítimas se deu a partir da ação penal contra os implicados, após constatada a existência de diversas possibilidades equivocadas na literatura e nas fontes de imprensa. Para perpetradores e depoentes da CPI, a normalização se deu a partir da assinatura do próprio indivíduo nos autos do legislativo, uma vez que erros de grafia também se mostraram recorrentes nos autos. Outras fontes apresentam Zuleika Silva ao invés de Zuleica de tal, sendo este um nome mais confiável.
} 
A experiência ensina que crimes dessa natureza, cometidos em circunstâncias peculiares procuradas pelos agentes (pequeno grupo de pessoas solidárias, locais êrmos, ocultação de vestígios, reiteração periódica), obedecem a um crescendo. Não é admissível que, logo na primeira viagem, houvesse três vítimas. Mais lógico e provável é que lançamentos isolados fôssem anteriormente feitos, cercados de cuidados e cautelas, ficando ignorados. Daí o encorajamento, a reiteração em maior escala e até mesmo menor perfeição nos meios e modos de execução culminando pelo fracasso do atentado contra Olindina, tão bem narrado a fls. 640-641v. pela própria vítima (GUANABARA, 1965, p.337).

A CPI, proposta inicialmente pelo deputado Ib Teixeira, do Partido Trabalhista Brasileiro (PTB), contou com o apoio dos deputados petebistas Amando da Fonseca, José Talarico, Geraldo Moreira, Luis Correia, Rubens Macedo, Paulo Alberto Monteiro de Barros, Saldanha Coelho, Sinval Sampaio, Edna Lott, Hércules Corrêa, Horácio Franco, Velinda Maurício da Fonseca e Francisco José Dutra Júnior, além de Gerson Bergher, Jamil Haddad, Adalgisa Nery e Pedro Fernandes, estes do Partido Socialista Brasileiro (PSB). Criada pela Resolução no 34/1963, publicada em 8 de fevereiro de 1963 no Diário da Assembleia Legislativa, a comissão contou com nove membros e três meses para executar seus trabalhos, prazo posteriormente prorrogado para "[...] o bom e leal cumprimento da sua missão" (GUANABARA, 1963, p.7).

A primeira reunião da CPI ocorreu em 12 de fevereiro de 1963, visando à eleição de seu presidente e vice-presidente, bem como a tomada de medidas administrativas necessárias para o pleno exercício de suas atividades. Foram eleitos, como presidente e vice-presidente da comissão, respectivamente os deputados José Bonifácio Diniz de Andrada (Partido Social Democrático, PSD) e Ib Teixeira (PTB). A relatoria ficou a cargo de Paulo Duque (PR). Os demais membros foram os deputados Célio Borja e Nina Ribeiro (UDN), Sinval Sampaio (PTB), Everardo Magalhães Castro (Partido Democrata Cristão, PDC), Nelson José Salim (Partido Social Trabalhista, PST) e Rubem Cardoso (Partido Social Progressista, PSP) (GUANABARA, 1963, p.7-8). As fontes de imprensa nos sinalizam que o deputado Everardo Magalhães Castro (PDC) se 
desligaria da CPI no início de suas atividades (ULTIMA HORA, 14/02/1963), havendo referências posteriores a Paulo Alberto Monteiro de Barros ${ }^{4}$ (PTB), seu possível substituto. A primeira sessão também contou com a aprovação de uma diligência no Regimento de Cavalaria Caetano de Faria, onde os implicados estavam detidos. ${ }^{5}$

Com base na sentença, as prisões preventivas de José Mota, Pedro Saturnino dos Santos, Nilton Gonçalves da Silva e Mário Teixeira ocorreram em 28 de janeiro de 1963. Alcino Pinto Nunes, chefe do SRM, foi preso preventivamente em 2 de fevereiro. Por fim, os motoristas Anísio Magalhães da Costa e Martinho José Graciano foram presos em 12 de fevereiro (GUANABARA, 1965, p.335). Muito embora outros nomes se apresentem ao longo das fontes aqui analisadas, veremos que as responsabilizações não vão para além destes sete agentes.

A primeira sessão com a presença de implicados diretos na "Operação mata-mendigos" ocorreu em $1^{\circ}$ de março de 1963, quando foram ouvidos Pedro Saturnino dos Santos, José Mota e Nilton Gonçalves da Silva. Conforme seu depoimento, Pedro Saturnino dos Santos era guarda noturno lotado no $21^{\circ} \mathrm{DP}$, mas passou a prestar serviços no SRM por restrições de espaço na delegacia de Guarda Noturna. O depoente negou envolvimento nos crimes, afirmando ter realizado apenas viagens de deportação para outros estados, mas que fora coagido a confessar sua participação em execuções durante o inquérito criminal (GUANABARA, 1963, p.10-11).

Mota iniciara sua prestação de serviços no SRM em outubro de 1957, sob a chefia de Adalberto Symphronio do Couto, e alegara que nenhuma viagem de deportação ocorrera nesse período ou entre agosto e dezembro de 1960, quando Lorival da Costa Maia chefiou o SRM. As viagens teriam se

\footnotetext{
${ }^{4}$ Também conhecido como Artur da Távola, pseudônimo utilizado em suas colunas no jornal $O$ Globo.

${ }^{5}$ Finda a primeira sessão, os membros da CPI rumaram ao Regimento de Cavalaria Caetano de Faria e foram impedidos de adentrar nas dependências. Diante disso, apuraram causas do impedimento. Em 24 de julho de 1963 - após votação com quatro votos favoráveis e três desfavoráveis - um relatório preliminar responsabilizou o secretário de Segurança Pública, Gustavo Borges, por barrar o livre acesso dos parlamentares no local. O relatório foi encaminhado à Justiça.
} 
iniciado em janeiro de 1961, quando Cecil de Macedo Borer assumiu a Delegacia de Vigilância (GUANABARA, 1963, p.11-12). Como veremos, essas afirmações não se sustentariam. $\mathrm{O}$ guarda civil elencou várias viagens para os estados de Minas Gerais e São Paulo ao longo de 1961, com a autorização de Borer e a participação de quase todos os detetives do SRM. Segundo o depoente, Borer ressarcia o abastecimento das viaturas mediante apresentação de recibos, mas o procedimento fora alterado e a gasolina passou a ser fornecida pelo gabinete do chefe de polícia, através do oficial Antônio Malfitano (GUANABARA, 1963, p.12-14).

Entre janeiro e agosto de 1962, o SRM foi chefiado por Galdino Regis Neto e, posteriormente, por Alcino Pinto Nunes. Mota não prestou serviços para a subseção entre janeiro e maio de 1962, quando esteve transferido para o $26^{\circ}$ Distrito Policial (DP), e negou sua participação em viagens de deportação durante a gestão de Galdino Regis Neto (GUANABARA, 1963, p.15). Permaneceu como responsável do expediente durante a gestão de Alcino Pinto Nunes, mas também ficou "[...] responsável pelos abrigados, que recuperados colaboravam espontaneamente em diversos setores da Seção" (GUANABARA, 1963, p.15). Conforme depoimento, várias viagens de deportação foram realizadas durante essa gestão, contando com sua participação e dos demais funcionários, como a viagem à cidade fluminense de Campos com a viatura 677, quando os agentes José Peres Prata, Ananias Eduardo da Silva e o motorista Costa foram perseguidos pelo repórter Amado Ribeiro, do Ultima Hora. Diversas reportagens sobre o caso foram publicadas entre o final de agosto e o início de setembro de 1962. (GUANABARA, 1963, p.15-16).

Com a repercussão das reportagens, conforme abordado, foi baixada uma ordem de serviço proibindo as viaturas do DESP de atravessar as barreiras estaduais sem autorização do chefe de polícia. Todavia, as deportações continuaram a ocorrer dentro do estado da Guanabara, para locais como a Barra da Tijuca, Recreio dos Bandeirantes, Jacarepaguá, Estrada Grajaú-Jacarepaguá, Campo Grande e Santa Cruz, sempre autorizadas por Cecil Borer, mesmo após sua saída da Delegacia de Vigilância para dirigir o Departamento de Ordem 
Política e Social (DOPS) da Guanabara (GUANABARA, 1963, p.16). Mota também relatou que Pedro Saturnino dos Santos já participava das deportações na gestão de Galdino Regis Neto, e que Nilton Gonçalves da Silva passou a participar somente na gestão de Alcino Pinto Nunes.

A síntese do depoimento de Mota apresentada no parecer do relator coincide com aquela apresentada pelo Ultima Hora em $1^{\circ}$ de março de 1963, concluindo que: [1] o depoente não teve participação nos crimes contra "mendigos"; [2] as mortes por afogamento tiveram início na gestão de Alcino Pinto Nunes, uma vez que antes eram realizadas apenas viagens de deportação; [3] Mota “[...] era o encarregado do expediente e pràticamente o dono do S.R.M. porque tinha mais preparo que os outros e era o único que sabia escrever à máquina"; [4] todos os funcionários tinham conhecimento das deportações; [5] José Mota desconhecia se Alcino Pinto Nunes tinha ciência dos crimes; [6] Pedro Saturnino dos Santos foi apontado como culpado pelos crimes; [7] Mota afirmou ter apenas presenciado os indigentes serem atirados ao rio, negando qualquer participação nos crimes; [8] Mota recebia ordens dos superiores para que os "mendigos" fossem apenas abandonados nas estradas; e [9] os executores dos crimes eram Pedro Saturnino dos Santos e Nilton Gonçalves da Silva.

O parecer segue com uma declaração textual de Mota afirmando que a ideia de atirar as vítimas em rios derivou do retorno destes à Guanabara, sendo na maioria indivíduos deixados na estrada, “[...] cachaceiros que viviam bebendo nas ruas, que não queriam nada com o trabalho, malucos". O guarda civil negou participação na matança, mas assumiu participação nas deportações (GUANABARA, 1963, p.18-19).

Uma vez que Pedro Saturnino dos Santos e José Mota negaram todas as acusações ou questionamentos, a comissão procedeu a uma acareação dos depoentes junto a Nilton Gonçalves da Silva. Inicialmente foram interrogados Pedro Saturnino dos Santos e José Mota, esclarecendo que os detidos no Regimento da Cavalaria Caetano de Faria teriam combinado em negar qualquer participação nos crimes. No decorrer da acareação, Pedro Saturnino dos Santos 
assumiu a participação em quatro "viagens sem volta" e afirmou que a ideia de atirar as vítimas nos rios partiu de José Mota (GUANABARA 1963, p.20). O número de viagens de extermínio é consonante com a ação penal (GUANABARA, 1965, p.336).

Nilton Gonçalves da Silva foi interrogado pela CPI antes da acareação, confirmando a presença de agentes externos ao SRM na execução de atividades e confessando sua participação em viagens de deporte dentro e fora do estado da Guanabara, a convite de José Mota. Durante a acareação, Mota e Pedro Saturnino dos Santos confirmaram suas participações e Nilton Gonçalves da Silva permaneceu negando envolvimento nos crimes (GUANABARA, 1963, p.21).

Na mesma sessão foram ouvidos os motoristas Anísio Magalhães da Costa, Mário Teixeira e Martinho José Graciano. O primeiro confirmou a participação de Nilton Gonçalves da Silva, José Mota e Pedro Saturnino dos Santos, que "[...] saíam juntos do carro para levar a cabo a trágica missão, em cima da ponte" (GUANABARA, 1963, p.26). Também indicou certo controle burocrático em fichas, iniciado na gestão de Antônio Malfitano e continuado na gestão de Alcino Pinto Nunes, especificando o número da viatura, saída, entrada e a quantidade de detidos que eram levados. As viagens seriam especificadas somente como "serviço" ou "ronda", e Mota orientaria quanto ao preenchimento das fichas, especificando a quantidade de indivíduos a ser discriminada. Quanto à gasolina excedente, o depoente explica que Mota fazia ligações para o gabinete do chefe de polícia para apanhar a gasolina, sendo as ordens verbais, sem registro, e o recibo era deixado na garagem quando Malfitano não estava em seu gabinete. Anísio Magalhães da Costa teria confirmado a ciência de "autoridades superiores" sobre o fornecimento de gasolina (GUANABARA, 1963, p.26-29).

O motorista Mário Teixeira afirmara ter permanecido na viatura nas quatro viagens de deportação em que participou, sem descer para auxiliar os policiais e sem desligar o motor. Quanto às viagens de extermínio, confirmou as declarações de Anísio Magalhães da Costa, adicionando elementos a respeito da 
viagem de 17 de janeiro de 1963, quando conduziu a viatura (GUANABARA, 1963, p.29-30). A sentença é consoante ao depoimento e traz a participação do motorista apenas nessa viagem de extermínio (GUANABARA, 1965, p.334).

Ambos os motoristas afirmaram ter participado por ordens de José Mota, mas alegaram não ver as vítimas sendo atiradas aos rios (GUANABARA, 1963, p.29-30). Conforme a matéria de fato da sentença, “Anísio Magalhães da Costa, vulgo Caçador, confessa (fls. 181, 2. ${ }^{\circ}$ volume) que participou de "três lançamentos"” (GUANABARA, 1965, p.336), sem especificar em quais das viagens ele teria participado ativamente nos crimes. $\mathrm{O}$ motorista participara das viagens de 15 de outubro de 1962, 19 de outubro de 1962, e 7 de janeiro de 1963 (GUANABARA, 1965, p.334).

Martinho José Graciano admitiu sua participação numa das viagens, mas sem envolvimento nos crimes. O motorista também confirmou a participação de Nilton Gonçalves da Silva em uma viagem (GUANABARA, 1963, p.30). A sentença especifica que Martinho José Graciano participara da segunda viagem, em 19 de outubro de 1962, quando testemunhou Nilton Gonçalves da Silva e Pedro Saturnino dos Santos realizarem os "lançamentos" (GUANABARA, 1965, p.336).

Após os depoimentos individuais, uma "acareação total" foi realizada pela CPI com José Mota, Pedro Saturnino dos Santos, Nilton Gonçalves da Silva, Mário Teixeira, Anísio Magalhães da Costa e Martinho José Graciano. A comissão adotou tal medida por constatar que todos os depoentes evadiam a responsabilidade pelos crimes. Pedro Saturnino dos Santos, José Mota e os motoristas reafirmaram a participação de Nilton Gonçalves da Silva, que veio a confessar seu envolvimento, apontando o inspetor Alcino Pinto Nunes como mandante. Com esta declaração, a atenção se voltaria para a autoria dos crimes, já que Mota apontava Nilton Gonçalves da Silva e Pedro Saturnino dos Santos como idealizadores, e estes apontavam Mota como responsável pelo extermínio (GUANABARA, 1963, p.31).

Ao longo da acareação, José Mota alegara que todos os funcionários do SRM participaram das viagens de deportação, sendo este serviço rotineiro. 
"Era o dia que caísse. Se estivesse um funcionário de serviço ele ia" (GUANABARA, 1963, p.32). Indagados quanto ao conhecimento do subchefe do SRM, José Peres Prata, acerca das viagens, os acareados foram unânimes em confirmar o fato. Os acusados confessaram um total de treze vítimas lançadas aos rios, saldo consonante com a sentença do juiz Roberto Talavera Bruce (GUANABARA, 1963, p.33; 1965, p.334).

O parecer da CPI apresenta um histórico do SRM: o regulamento do antigo Departamento Federal de Segurança Pública (DFSP), de agosto de 1945, subordinava a "Seção de Repressão à Mendicância" à Delegacia de Vigilância. Na gestão do chefe de polícia Pereira Lira, foi determinado que as atribuições da Seção fossem transferidas à Delegacia de Menores e, mais tarde, voltassem à Delegacia de Vigilância. Com a reformulação do regulamento do DFSP, em 1955, a seção foi omitida, mas figurava no organograma uma "Subseção de Mendicância” junto à Delegacia de Costumes e Diversões. O relator salienta que, apesar do organograma e do regulamento, o serviço sempre se subordinou à Delegacia de Vigilância. Salienta-se a "[...] desorientação administrativa e o pouco caso com que tem sido conduzido esse importante problema" (GUANABARA, 1963, p.34). Cumpre-nos lembrar que, com a transferência da capital federal para Brasília, em 1960, os serviços locais do DFSP se subordinaram provisoriamente ao governo da Guanabara sob a rubrica de Departamento Estadual de Segurança Pública (DESP) (ANTONIO, 2019, p.87).

O primeiro chefe do SRM, Adalberto Symphronio do Couto, prestou depoimento à CPI em 6 de março de 1963, quando declarou que José Mota era um funcionário exemplar e atribuiu a mudança de conduta do guarda "[...]'à [sua] saída ou falta de chefia enérgica"” (GUANABARA, 1963, p.35). O depoente menciona a criação de um livro de registros para os valores que os detidos portavam e prestação de contas enviada mensalmente à Delegacia de Vigilância, trazendo as ocorrências do SRM. Os relatórios, solicitados pela CPI e anexados ao processo, esclareceriam os seguintes aspectos: [1] os relatórios eram circunstanciados, deixando o chefe de polícia ciente de todas as atividades da Seção; [2] um "mapa-resumo" trazia dados estatísticos (como o número de 
recolhidos no estabelecimento, falsa mendicância, pedidos a autoridade, número de readaptados, maternidade, passagens concedidas, internamento de menores e motivos diversos); [3] tipificação da entrada de "mendigos" e as circunstâncias dos recolhimentos (esmolando, perambulando, dormindo, deficiência mental, espontânea); [4] origem dos "mendigos" (qual DP, serviço social, hospital, entre outros); [5] bem como a saída e encaminhamento dos “mendigos” (GUANABARA, 1963, p.35-36).

O item "embarcados para os Estados" apresenta o número de "mendigos" enviados mensalmente para fora da Guanabara, cujos dados foram sistematizados na Tabela 1. Quanto aos dados apresentados, atentamos que o início das práticas de registro, em 1958, não necessariamente implica no início das práticas de deportação propriamente ditas. Ademais, é possível que haja subnotificação, uma vez que os jornais indicam o trânsito forçado de "mendigos" como uma espécie de fenômeno regional em 1961, período com poucos registros (Cf. ANTONIO, 2019, p.87). Como veremos adiante, houve também mudanças nas formas de registro que reduzem a confiabilidade dos dados. Ainda assim, os números são elevados e apresentam a amplitude, antiguidade e sistematicidade das práticas, com especial destaque para os anos de 1958 e 1962. O relator aponta que a política deportar "mendigos" era adotada há anos, restando averiguar quando e como se iniciaram os homicídios (GUANABARA, 1963, p.40). 
Tabela 1 - Relação mensal de recolhidos enviados a outros estados (19581962)

\begin{tabular}{|c|c|c|c|c|c|}
\hline & 1958 & 1959 & 1960 & 1961 & 1962 \\
\hline Janeiro & - & $39^{S}$ & - & - & $0^{\mathrm{G}}$ \\
\hline Fevereiro & - & - & $18^{\mathrm{S}}$ & $1^{\mathrm{L}}$ & $2^{\mathrm{G}}$ \\
\hline Março & $39^{\mathrm{S}}$ & - & $10^{\mathrm{S}}$ & $0^{\mathrm{L}}$ & $0^{\mathrm{G}}$ \\
\hline Abril & $47^{\mathrm{S}}$ & - & $15^{\mathrm{S}}$ & $0^{\mathrm{L}}$ & $75^{\mathrm{G}}$ \\
\hline Maio & $57^{\mathrm{S}}$ & $54^{\mathrm{S}}$ & - & $0^{\mathrm{L}}$ & $30^{\mathrm{G}}$ \\
\hline Junho & $53^{S}$ & $65^{S}$ & $11^{Z}$ & $0^{\mathrm{L}}$ & $39^{G}$ \\
\hline Julho & $49^{S}$ & - & $9^{S}$ & $0^{\mathrm{L}}$ & $93^{\mathrm{G}}$ \\
\hline Agosto & $49^{S}$ & - & $4^{\mathrm{L}}$ & $0^{\mathrm{L}}$ & $0^{\mathrm{A}}$ \\
\hline Setembro & \multirow{3}{*}{$174^{\mathrm{S}}$} & $11^{\mathrm{S}}$ & $0^{\mathrm{L}}$ & $0^{\mathrm{L}}$ & $0^{\mathrm{A}}$ \\
\hline Outubro & & - & $1^{\mathrm{L}}$ & $0^{\mathrm{L}}$ & $0^{\mathrm{A}}$ \\
\hline Novembro & & - & $0^{\mathrm{L}}$ & $10^{\mathrm{L}}$ & $0^{\mathrm{A}}$ \\
\hline Dezembro & $49^{S}$ & - & $0^{\mathrm{L}}$ & $0^{\mathrm{L}}$ & $1^{\mathrm{A}}$ \\
\hline
\end{tabular}

Legenda: S - assinado por Adalberto Sympronio do Couto; Z - assinado por Zeferino Ladeira, chefe substituto; L - assinado por Lorival da Costa Maia; G - assinado por Galdino Régis Neto; A - assinado por Alcino Pinto Nunes.

Fonte: GUANABARA, 1963, p.36-40.

Também na sessão de 6 de março, foram ouvidos José Peres Prata (auxiliar de Alcino Pinto Nunes) e Galdino Regis Neto, que chefiou o SRM entre janeiro e julho de 1962. Prata confessou que, apesar de ser hierarquicamente superior a Mota, este era quem dava ordens no SRM, sendo as viagens de deportação conhecidas por todos os funcionários. As ocorrências eram relatadas oralmente a Mota. (GUANABARA, 1963, p.41). Galdino Regis Neto declarou ter participado de três viagens ordenadas por Lorival da Costa Maia para levar "mendigos" às suas cidades de origem, e que realizou uma viagem para abandoná-los nas estradas da Guanabara depois que a saída de viaturas para estados vizinhos foi proibida. Declarou ainda que a viatura era entregue abastecida e todos os funcionários tinham ciência da atividade (GUANABARA, 1963, p.40).

O parecer prossegue com uma síntese dos depoimentos prestados em 8 de março pelos agentes Ernesto de Moraes Cony, Ananias Eduardo da Silva e Ernani Alvarez. Entre contribuições pontuais, confessaram participações em viagens de deportação para os estados de São Paulo, Minas Gerais e do Rio de Janeiro, em que apenas os indivíduos que desejassem retornar às cidades de origem eram levados. Esclareceram que José Mota comandava o SRM nas 
ausências de Alcino Pinto Nunes, e as viagens eram sempre realizadas durante a noite, levando entre oito e dez detentos que eram deixados "[...] em locais movimentados e perto de fazendas" (GUANABARA, 1963, p.41-42).

Acacio Felippe Cavallero, funcionário da Delegacia de Vigilância e Capturas; Orlando Viroz Lanor, motorista da Assistência Policial; e Lorival da Costa Maia, ex-chefe do SRM, depuseram em 13 de março. Cavallero afirmou que os relatórios anteriormente citados possuíam três vias, sendo remetidas uma à Seção de Estatística da Secretaria de Segurança, outra para o Setor de Relações Públicas da Polícia e a terceira para o delegado (GUANABARA, 196, p.43). Lanor confessou ter realizado três viagens de deportação, todas com José Mota, que carregava os relatórios consigo nas viagens e chamava os detidos pelo nome ao liberá-los. O motorista também declarou que não eram feitas viagens de deportação em 1959, divergindo do histórico apresentado nos relatórios mensais entre 1958 a 1962 (GUANABARA, 1963, p.43-44).

Em seu depoimento, Lorival da Costa Maia afirmou ter ordenado a realização das viagens de "retorno" ao assumir o SRM, sendo necessária autorização superior, obtida mediante Cecil Borer e Pereira da Costa, sempre verbalmente. $\mathrm{O}$ depoente afirmou que era encarregado de escolher e relacionar os indivíduos que desejavam retornar aos estados de origem, e que as viagens eram realizadas por quase todos os funcionários do SRM. Cerca de 5000 "mendigos" teriam passado pelo SRM em 1960, e as viagens eram realizadas durante a noite devido à necessidade de rondas ostensivas com as viaturas durante o dia. Questionado quanto à subtração de bens dos detentos, o depoente esclareceu que estes eram inicialmente examinados na "sala dos expurgos", usualmente pelo permanente de serviço e outro policial que arrecadavam e descreviam os objetos num recibo, mediante suas ordens. Se o indivíduo fosse analfabeto, deficiente mental ou estivesse alcoolizado, os policiais prestavam testemunho sobre os bens recolhidos. O dinheiro era arrecadado e registrado em livro próprio, sob a guarda de Lorival da Costa Maia. Ao ser liberado, os pertences e valores eram devolvidos ao indivíduo (GUANABARA, 1963, p.46). 
O parecer atenta para as especificidades dos relatórios de deporte mensais, que eram claros quanto ao número de pessoas encaminhadas a outros estados durante a gestão de Symphronio do Couto (1958-1960), mas as viagens haviam desaparecido durante a gestão de Lorival da Costa Maia (1960-1961). Questionado sobre isso, o depoente esclareceu que os "recambiados" eram colocados em relatório próprio, na pasta de "mendigos liberados", sendo mantido o levantamento mensal de detidos, liberados ou conduzidos ao Abrigo Cristo Redentor e demais abrigos. Quanto à gasolina utilizada nas viagens fora do estado, o depoente menciona "[...] que um simples telefonema era o suficiente para obtê-la" (GUANABARA, 1963, p.46-47).

$\mathrm{Na}$ seção de 14 de março, o inspetor Alcino Pinto Nunes alegara desconhecer as viagens de deportação, as quais tomou ciência por meio da imprensa. $\mathrm{O}$ depoente justifica que as viagens ocorriam fora do seu horário de expediente. Posteriormente, confessou à CPI que Borer autorizava o deporte de "mendigos" que desejassem ir para outro estado, mas que ele "[...] nunca autorizou isso uma vêz que a sua preocupação era recuperar mendigos" (GUANABARA, 1953, p.48). Quanto às reportagens do Ultima Hora denunciando as deportações, Nunes relata que o fato foi comunicado ao Delegado de Vigilância, que lhe pediu para desmentir tais denúncias. Questionado sobre a gasolina excedente para as viagens, o depoente relatou nunca ter realizado pedidos ou autorizado as viagens. Em vista das sucessivas negativas acerca dos crimes e viagens de deportação, o inspetor foi acareado junto a José Mota, seguindo-se acareações entre ele, Mota e José Peres Prata e, posteriormente, com Mota e Nilton Gonçalves da Silva (GUANABARA, 1963, p.49).

José Mota perante afirmara que todas as viagens foram realizadas com pleno conhecimento do chefe do SRM, mediante comunicados verbais. O inspetor admite que era informado sobre tais viagens, realizadas dentro do estado da Guanabara para regiões como Jacarepaguá, Barra da Tijuca, etc. Quanto às práticas de extermínio, Mota isentou Nunes de qualquer envolvimento e confessou sua responsabilidade (GUANABARA, 1963, p.49- 
50). Conforme a matéria de fato da sentença, Nunes afirmou não ter conhecimento sobre a ordem de jogar "mendigos" nos rios ou abandoná-los nas estradas. Em acareação com os demais implicados repetiu que jamais permitiu anormalidades durante sua chefia (GUANABARA, 1965, p.336). O inspetor alegou que, algumas vezes, ao chegar na Seção, Mota e outro policial permanente do dia anunciavam a morte de algum detento com a expressão "[...] hoje, um fechou o paletó”. Ao indagá-los da causa mortis, diziam ser de causa "[...] natural, que dava um delírio [no indivíduo] devido à bebida, morrendo a seguir" (GUANABARA, 1965, p.338).

A acareação entre Nunes, Mota e Prata reafirmaria o conhecimento do inspetor e sua autorização para as viagens. Na terceira e última acareação, envolvendo Nunes, Mota e Nilton Gonçalves da Silva, Mota assume novamente sua responsabilidade em providenciar os detalhes das viagens, o que incluía a gasolina excedente, arranjada mediante autorização de Antônio Malfitano (quando era oficial de gabinete de Newton Marques Cruz). Nilton Gonçalves da Silva, ao contrário de Mota, buscou inocentar Nunes, afirmando que o inspetor desconhecia as irregularidades no SRM. Em determinado momento Pedro Saturnino dos Santos é convocado e reafirma que Nunes não tinha conhecimento sobre um suposto espancamento do "mendigo" Nestor Silva da Conceição, que prestou serviços no sítio do inspetor (GUANABARA, 1963, p.50-51). Conforme a matéria de direito da sentença, Alcino Pinto Nunes foi implicado nos crimes por omissão, uma vez que "[...] jamais houve um chefe de serviço tão antichefe" (GUANABARA, 1965, p.353).

Em seu depoimento à CPI, Cecil Borer confirma ter ciência das viagens de deportação para outros estados, sendo estas realizadas somente com indivíduos que desejassem ir ao "ponto de procedência", termo utilizado para se referir às cidades mais próximas e possíveis para as deportações (GUANABARA, 1963, p.52-53). Esta versão também é sustentada durante o inquérito criminal (GUANABARA, 1965, p.342). Questionado sobre os indivíduos oriundos de cidades e estados mais afastados da Guanabara, Borer 
confessou a inviabilidade de tais viagens, e que estes acabavam sendo liberados (GUANABARA, 1963, p.52-53).

Diante de controvérsias entre Borer, Nunes e Mota, a sessão foi seguida de uma acareação para "[...] saber, com certeza, se o Delegado de Vigilância na época, superior imediato do Inspetor Alcino, o delegado Cecil Borer, tinha ou não ciência das viagens chamadas 'deportação"” (GUANABARA, 1963, p.54). Mota e Nunes persistem na negativa de que Borer conhecia tais práticas (GUANABARA, 1963, 54-55).

Entre os depoimentos de 27 de março, foram ouvidos Antônio Coelho de Rezende Neto (engenheiro do Departamento Nacional de Obras e Saneamento), Luiz Gonzaga da Costa Silva (vendedor ambulante) e Nestor Silva da Conceição (pedreiro, conhecido também como "Gaúcho").

Responsável pela fiscalização e supervisão das obras de saneamento na Baixada Fluminense, incluindo os rios Guandu e da Guarda, onde os crimes foram cometidos, Antônio Coelho de Rezende Neto explicou que, após a inauguração da Usina Nilo Peçanha, a descarga de água do rio Gaundú-Assu aumentou seu volume de $40 \mathrm{~m}^{3} / \mathrm{seg}$ para 140 a $160 \mathrm{~m} 3 / \mathrm{seg}$, e alguns cadáveres começaram a surgir na zona chamada "comporta do Guandú" de 1955 em diante (GUANABARA, 1963, p.56). Conforme o depoente, cerca de treze cadáveres apareceram nesta comporta, sendo removidos pelas delegacias de Itaguaí e de Santa Cruz. O engenheiro esclarece que “[...] os cadáveres jogados em qualquer ponto do Guandú, forçosamente, êles param, por ser uma zona de remanso e de desnível muito grande. O número, o ano a frequência não sei, porque, infelizmente não tenho um livro de registro" (GUANABARA, 1963, p.57). Questionado pelo deputado Nelson José Salim (PST) acerca destes "mendigos", se eram jogados no estado do Rio de Janeiro ou da Guanabara, o depoente responde não ter certeza se os cadáveres eram de "mendigos", mas os que apareceram nas comportas do Guandu só podiam vir do estado do Rio de Janeiro. O depoente teria deixado uma planta da região à disposição.

O vendedor ambulante Luiz Gonzaga da Costa Silva, detido em 8 de agosto de 1962 e levado ao SRM, prestou esclarecimentos à CPI alegando que 
nunca testemunhou convites para que indivíduos retornarem voluntariamente ao estado de origem, sendo estes colocados à força nas viaturas e deportados. Afirmou ainda ter presenciado o espancamento do "mendigo" Djalma Alves da Silva por Nilton Gonçalves da Silva. Em relação aos pertences devolvidos a quem dava entrada no SRM, a importância em dinheiro era sempre inferior àquela inicialmente recolhida. $\mathrm{O}$ vendedor também alegou que, durante todo o tempo em que esteve detido (cerca de seis meses), permaneceu dentro da cela sem idas ao pátio ou banhos de sol porque, "[d]isseram que eu estava à disposição da Justiça" (GUANABARA, 1963, p.57-58).

O parecer do relator é omisso quanto ao espancamento e morte de Djalma Alves da Silva, mas a matéria de fato na sentença de pronúncia dos implicados traz detalhes sobre o ocorrido. Com base na confissão de José Mota, este golpeou a vítima com um cabo de vassoura que se quebrou ao meio. Mota não teria presenciado a violência cometida pelo coautor do crime, Nilton Gonçalves da Silva, pois teria se dirigido ao segundo andar da SRM assim que iniciadas as arbitrariedades. Nilton Gonçalves da Silva, por sua vez, acusa Mota de ter espancado a vítima com uma régua, “[...] dando pancadas consecutivas de um lado e outro das clavículas e, a seguir, nas partes laterais do pescoço" (GUANABARA, 1965, p.337). Nilton Gonçalves da Silva admite que também espancou a vítima com uma régua, desferindo ao menos dez golpes em suas costas. Após as arbitrariedades, Djalma Alves da Silva foi conduzido a uma das celas do SRM, vindo a falecer 48 horas depois, em $1^{\circ}$ de outubro de 1962 (GUANABARA, 1965: 338). A matéria de direito contesta o laudo cadavérico, onde consta que a vítima teve uma "morte súbita" causada por uma "broncopneumonia" e "osteatese hepática" [sic] (GUANABARA, 1965, p.344345). Esteatose hepática é o acúmulo de gordura no fígado, podendo decorrer de diversos fatores, como má alimentação ou uso excessivo de álcool. A evolução de ambos os diagnósticos é incompatível com uma eventual morte súbita.

Em depoimento, Nestor Silva da Conceição disse que foi encaminhado ao SRM por um transeunte e passou a trabalhar no local como pedreiro e, após 
20 dias, o inspetor Alcino Pinto Nunes o contratou para cuidar de seu sítio, onde permaneceu por apenas um dia. Nestor encontrara um caixote de armas no sítio, o que gerou questionamentos para com o inspetor. Ao retornar ao SRM (o relatório não deixa claro se espontânea ou forçosamente), foi espancado por Pedro Saturnino dos Santos e Nilton Gonçalves da Silva, fato confessado pelo primeiro. Questionado acerca das viagens, o depoente afirmou ter presenciado algumas (GUANABARA, 1963, p.59).

Acerca da posse indevida das armas provenientes do DOPS, a sentença novamente complementa o parecer do inquérito parlamentar. Alcino Pinto Nunes confessou a ideia de fazer um mostruário, em número de quatro caixas, mediante autorização do detetive Adariton. $\mathrm{O}$ inspetor alegou que quis devolver as armas, mas que “[...] não desejaram recebê-las porque o momento não era oportuno; acabou levando-as para o seu sítio, na estrada Rio-Magé, onde ficaram guardadas, esperando a oportunidade de devolução" (GUANABARA, 1965, p.339). A conduta foi enquadrada no artigo 312, caput, do Código Penal, que tipifica o crime de peculato, quando o funcionário público se apropria de bem móvel ou valor em espécie, público ou particular (GUANABARA, 1965, p.354). Apesar de José Mota ser acusado de subtrair bens dos indivíduos que adentravam o SRM, como veremos a seguir, sua sentença de pronúncia não contempla o crime de peculato.

Em nova sessão, ocorrida em 28 de março, prestaram depoimento três "mendigos". O primeiro, José Gomes Sobrinho, relatou que foi detido em janeiro de 1963 por policiais do SRM e não sofreu ou presenciou maus-tratos, e que Nestor Silva da Conceição "[...] prestava serviços policiais, na seção, chegando mesmo a sair com as turmas, voltando tarde da noite" (GUANABARA, 1963, 60). O depoimento também confirma a subtração de bens dos detidos. $\mathrm{O}$ segundo depoente, Waldemar de Almeida, reafirmou ser comum que os policiais se apossassem do dinheiro arrecadado. O terceiro depoimento não é adensado no parecer, mencionando-se apenas sua presença na viagem de deportação para a cidade de Campos, sob a chefia de José Peres Prata (GUANABARA, 1963, p.60-61). 
$\mathrm{Na}$ matéria de fato da sentença, diversas testemunhas relataram a subtração de bens que eram entregues a José Mota. Merecem destaque Altair da Silva, Sebastião Severino da Silva, Altamiro Martins Xavier, Maria Nazareth dos Santos e Celeste Maria de Jesus. Altair da Silva alegara que foi ameaçado de ser jogado no rio Guandu por José Mota ao pedir a devolução de seus bens. Sebastião Severino da Silva confirmou as acusações de Altair da Silva contra Mota. Altamiro Martins Xavier, "ex-mendigo" agregado ao SRM como barbeiro, alegara que dinheiro, objetos como relógios, cordões de ouro e outros pertences eram entregues ao policial durante as revistas, podendo informar “"[...] com tôda a segurança, que ficavam em poder do chefe Mota". Maria Nazareth dos Santos e Celeste Maria de Jesus também confirmam a subtração de bens e a entrega destes a Mota, mencionando o caso de uma família mineira, quando uma quantia superior a 100 mil cruzeiros foi receptada (GUANABARA, 1965, p.339-340).

Visando maiores esclarecimentos sobre o fornecimento de gasolina, Antônio Malfitano foi convocado a depor em 4 de abril. O parecer aponta várias contradições entre seu depoimento e afirmativas anteriores de José Mota e Alcino Pinto Nunes. Entre as contradições constam as seguintes afirmativas: [1] os assuntos do SRM não eram tratados com ele, mas apenas com o delegado de Vigilância, a quem a Subseção era subordinada; [2] todas as providências para o SRM eram sempre requeridas pela Delegacia de Vigilância, e nunca diretamente pela Subseção; [3] a liberação de viaturas para viagens fora do estado pelo Serviço de Transporte não podia ser realizada sem a prévia autorização do Gabinete do chefe de polícia, sendo que foram realizados 1200 atendimentos de viatura apenas em 1962, englobando todos os serviços; [4] e que nunca recebera pedidos do SRM para suplementação de gasolina (GUANABARA, 1963, p.62).

Diante das contradições, uma nova acareação foi convocada, aprovada para 16 de abril. José Mota reafirmou suas declarações acerca dos vários telefonemas a Malfitano solicitando gasolina para as viagens, uma vez que a autorização do chefe de polícia era indispensável para tal. Embora a solicitação 
fosse para realizar viagens para fora do estado, este ponto não era esclarecido. Alcino Pinto Nunes relatou que jamais solicitou combustível a qualquer pessoa do gabinete, seja pessoalmente ou por telefone, mas tinha conhecimento de que José Mota solicitava gasolina conforme informações de José Peres Prata. Malfitano manteve as declarações anteriores, negando qualquer contato com Mota (GUANABARA, 1963, p.63-64).

O delegado Aristides Ventura depôs na sessão de 19 de abril, esclarecendo a CPI acerca do funcionamento e das dinâmicas da Delegacia de Vigilância, visto que, quanto aos fatos relacionados à chacina, "[...] pouco ou quase nada pôde informar". Alcino Pinto Nunes já dirigia o SRM quando Ventura assumiu a Delegacia de Vigilância e Capturas, e ali foi mantido por ser considerado um bom policial. Ventura alegou desconhecer a presença e atuação de Pedro Saturnino dos Santos e Nilton Gonçalves da Silva, mas sabia da presença de José Mota. O depoente apontou as dificuldades e a sobrecarga da Delegacia de Vigilância e Capturas, trazendo dados à CPI e colocando-os a par das rotinas, esclarecendo que, em virtude do excesso e da diversidade de serviços, a delegacia não fiscalizava rigorosamente o SRM, cujo controle era pautado nos relatórios mensais emitidos localmente (GUANABARA, 1963, p.64).

Em 22 de abril de 1963, Newton Marques Cruz prestou depoimento à CPI por ser chefe de polícia na época do morticínio. Inicialmente, o depoente afirmou que tomou ciência dos crimes em janeiro, quando recebeu uma cópia do registro de ocorrências da delegacia de Santa Cruz, e que desconhecia as chamadas viagens de deportação. Em seguida, apontou aos membros da comissão que os "[...] os canais normais para a resposta ao requerimento de informações do deputado Affonso Arinos Filho, seriam: Seção de Mendicância, Delegacia de Vigilância, Chefatura de Polícia e Palácio Guanabara" (GUANABARA, 1963, p.65). Esclareceu que as informações do requerimento passaram por ele e os fatos foram todos negados pelo SRM. Todavia, mesmo com a negativa, Marques Cruz ordenou ao Serviço de Transportes que o trânsito de viaturas para fora do estado fosse vedado. 
O depoente é incisivo quanto à falta de competência do chefe de polícia no fornecimento de gasolina ao SRM, e alega como cautelar o ato que impedia o tráfego interestadual de viaturas sem sua autorização expressa. Marques Cruz persiste negando o fornecimento de combustível pelo Gabinete, apontando a coordenação de transportes da Diretoria de Transportes do estado como órgão competente para o assunto, além de declarar que nunca questionou Malfitano sobre o assunto (GUANABARA, 1963, p.67).

A matança de "mendigos" nos rios Guandu e da Guarda por oficiais do SRM, tema principal do inquérito parlamentar, é omitido das ressalvas na conclusão do parecer. Não se discorre sobre o número total de vítimas, o número de viagens que resultaram em mortes e nem os agentes policiais envolvidos em cada viagem. O parecer aponta sua conclusão como maior mérito da comissão, bem como a apresentação dos crimes cometidos contra "mendigos" e a prestação de esclarecimentos à opinião pública. Destaca-se também um anexo com a relação de indivíduos enviados ao Abrigo Cristo Redentor pelo SRM entre 1962 e janeiro de 1963, “[...] muito embora pouca ou nenhuma relação tinha haver [sic] com os fatos aqui analizados [sic]". Por fim, a comissão apresenta um projeto de resolução aprovando as conclusões do parecer e o envio dos três volumes do processo e documentos anexos à Justiça do estado (GUANABARA, 1963, p.68-71).

É notável a frustração ou perda de foco das atividades parlamentares se confrontarmos as conclusões do relator com supostos objetivos da CPI noticiados pelo jornal Ultima Hora. A comissão supostamente avaliaria o grau de participação do governador Carlos Lacerda nas deportações e as providências adotadas por ele ou pelo chefe de polícia ao tomarem ciência das práticas em agosto de 1962, bem como se as ordens de assassinar "mendigos" partiram de Cecil Borer ou Newton Marques Cruz (ULTIMA HORA, 05/02/1963). Como observamos, não se constroem evidências, ainda que testemunhais, de envolvimento das autoridades almejadas pelos parlamentares. Mesmo o papel de esclarecimento da opinião pública é questionável ao percebermos que faltam dados tão necessários sobre o conjunto de crimes 
cometidos, sua extensão, gravidade, envolvidos diretos e vítimas. O diagnóstico de uma leitura atenta do documento beira a obviedade: enquanto dispositivo político, e não jurídico, os reais objetivos se frustram conforme as premissas iniciais paulatinamente perdem sustentação. Entretanto, o documento é de suma importância para observar dinâmicas de dispersão do poder de mando e as janelas de negligência e delinquência que afloram da dinâmica burocrática.

Uma tentativa de compreensão estrita do caso: a sentença de pronúncia

A sentença de pronúncia sinaliza o inquérito parlamentar ainda não concluído quando do pronunciamento, mas refugia-se no princípio da independência dos poderes, constante na Constituição do Estado da Guanabara e na Constituição Federal de 1946, para desvincular-se de suas eventuais conclusões. Roberto Talavera Bruce, o juiz prolator, explica que inquéritos administrativos, parlamentares e criminais podem ser sincrônicos e divergentes quanto às suas conclusões, ficando cada qual em seu estrito domínio, e que os juízes devem chegar a conclusões próprias a partir das provas contidas nos autos forenses. $\mathrm{O}$ caráter puramente político do inquérito parlamentar resultaria também em sua invalidade como inquérito judiciário preliminar (GUANABARA, 1965, p.352).

Embora o parecer da CPI seja omisso sobre a matança em si, dando mais peso às deportações para outros estados, a sentença de pronúncia se debruça sobre denúncias pontuais e bem delimitadas, trazendo uma apuração das arbitrariedades com alto grau de detalhamento. Ao todo, foram quatro viagens de extermínio confessadas durante a investigação criminal e objeto da ação penal, às quais se soma a morte por espancamento de Djalma Alves da Silva.

A primeira viagem, realizada em 15 de outubro de 1962, contou com a participação de José Mota, Pedro Saturnino dos Santos, Anísio Magalhães da Costa e Nilton Gonçalves da Silva. Três vítimas foram mortas no rio Guandu: Elias Marcondes, Expedito Jesus Vieira e José dos Santos. Das vítimas, apenas 
Elias Marcondes teve exame cadavérico (Guia n 35) (GUANABARA, 1965, p.334, 336).

A segunda viagem, realizada em 19 de outubro de 1962, contou com a participação de José Mota, Pedro Saturnino dos Santos, Nilton Gonçalves da Silva, Anísio Magalhães da Costa e Martinho José Graciano. Quatro vítimas foram mortas no rio Guandu: José Vital da Silva, Antônio Maia da Conceição, Sebastião Ribeiro Ambrósio e Ari Loiola Barata. Todas as vítimas tiveram exame cadavérico (Guias n 50, 49, 48 e 38, respectivamente) (GUANABARA, 1965, p.334, 336).

A terceira viagem, realizada em 7 de janeiro de 1963, contou com a participação de José Mota, Pedro Saturnino dos Santos e Anísio Magalhães da Costa. Entre as vítimas jogadas no rio Guandu, apenas Olga Pereira dos Santos veio a óbito. Pedro Francisco Cachoeiro escapou nadando, Marcionília Catarina foi abandonada pela viatura na estrada Grajaú-Jacarepaguá e Maria Luiza do Socôrro foi violentada sexualmente por José Mota numa estrada secundária entre Santa Cruz e Campo Grande. A única vítima fatal não passou por exame cadavérico (GUANABARA, 1965, p.334, 336).

A quarta e última viagem arrolada na ação penal, realizada em 17 de janeiro de 1963, contou com a participação de José Mota, Pedro Saturnino dos Santos, Nilton Gonçalves da Silva e Mário Teixeira. Entre as vítimas jogadas no rio da Guarda estão Zuleica de tal, Geraldo Pereira, José de tal, Eunice Marques Evangelista, Nilton Marques dos Santos e Olindina Alves Japiassu, sendo esta a única sobrevivente. Todas as vítimas fatais passaram por exame cadavérico (Guias $n^{\circ}$ 13, 8, 7, 6 e 5, respectivamente). Acerca da condição dos corpos encontrados, menciona-se apenas os de José de tal e Geraldo Pereira, ambas vítimas da quarta viagem, sendo que o primeiro foi amarrado e baleado, sem constar a quantidade de tiros desferidos; e o segundo estaria em avançado estado de decomposição (GUANABARA, 1965, p.334, 336, 343).

Apesar do crime sexual contra Maria Luiza do Socôrro ser brevemente abordado na sentença, este não foi objeto da ação penal por falta de queixa ou 
representação, ou seja, ausência de denúncia da vítima ou de terceiros ${ }^{6}$. O juiz Roberto Talavera Bruce discorre sobre o fato como atentado violento ao pudor, tipificado no artigo 214, caput, e não como estupro, tipificado no artigo 213, caput do Código Penal à época. Tal enquadramento decorre do conceito de “conjunção carnal”, necessário à tipificação penal de estupro e inaplicável ao ato em questão, uma vez que Maria Luiza do Socôrro foi coagida a coito anal mediante violência (GUANABARA, 1965, p.345). A conjunção carnal é compreendida como encontro entre os órgãos sexuais masculino e feminino, e qualquer outra forma de conjunção era enquadrada como "ato libidinoso", alterando a tipificação penal. O crime sexual contra Maria Luiza do Socôrro nos leva a questionar também a ausência de crime de peculato atribuído a José Mota, possivelmente pela ausência material de provas.

As denúncias remetidas ao judiciário pelo Ministério Público não correspondem exatamente às penas pronunciadas pelo juiz prolator. Conforme a promotoria, Alcino Pinto Nunes teria incorrido treze vezes em homicídio quadruplamente qualificado (art. 121, $\S 2^{\circ}$, ns. I, II, III e IV), uma vez em homicídio duplamente qualificado (art. 121, § $2^{\circ}$, ns. II e IV), abuso de poder com coautoria de crime e concurso material (art. 350, Parágrafo Único, ns. III e IV combinado com art. 25 e art. 51) e peculato (art. 312); José Mota teria incorrido treze vezes em homicídio quadruplamente qualificado, uma vez em homicídio duplamente qualificado e abuso de poder com coautoria de crime e concurso material; Pedro Saturnino dos Santos teria incorrido treze vezes em homicídio quadruplamente qualificado e abuso de poder com coautoria de crime e concurso material; Nilton Gonçalves da Silva teria incorrido doze vezes em homicídio quadruplamente qualificado, uma vez em homicídio duplamente qualificado e abuso de poder com coautoria de crime e concurso material; Anísio Magalhães da Costa teria incorrido oito vezes em homicídio quadruplamente qualificado e abuso de poder com coautoria de crime e

\footnotetext{
${ }^{6}$ A prática de estupro foi tipificada como crime hediondo em 1990. O atentado violento ao pudor foi eliminado do Código Penal em 2009 e a tipificação de estupro foi ampliada. Desta forma, a partir de 2009, casos como de Maria Luiza do Socôrro prescindem de queixa ou representação.
} 
concurso material; Mário Teixeira teria incorrido cinco vezes em homicídio quadruplamente qualificado e abuso de poder com coautoria de crime e concurso material; e Martinho José Graciano teria incorrido quatro vezes em homicídio quadruplamente qualificado com coautoria de crime e concurso material (GUANABARA, 1965, p.334-335).

A sentença de pronúncia, por sua vez, responsabiliza Alcino Pinto Nunes por treze homicídios triplamente qualificados (art. $121, \S 2^{\circ}$, ns. I, III e IV) e um homicídio duplamente qualificado (art. 121, § $2^{\circ}$, ns. I e IV), sempre envolvendo violência arbitrária com coautoria de crime e concurso material (art. 322 combinado com art. 25 e art. 51), além de peculato (art. 312); José Mota foi responsabilizado por treze homicídios triplamente qualificados e um homicídio duplamente qualificado, sempre envolvendo violência arbitrária com coautoria de crime e concurso material; Pedro Saturnino dos Santos foi responsabilizado por treze homicídios triplamente qualificados envolvendo violência arbitrária com coautoria de crime e concurso material; Nilton Gonçalves da Silva foi responsabilizado por doze homicídios triplamente qualificados e um homicídio duplamente qualificado sempre envolvendo violência arbitrária com coautoria de crime e concurso material; Anísio Magalhães da Costa foi responsabilizado por oito homicídios triplamente qualificados envolvendo violência arbitrária com coautoria de crime e concurso material; Mário Teixeira foi responsabilizado por oito homicídios triplamente qualificados envolvendo violência arbitrária com coautoria de crime e concurso material; e Martinho José Graciano foi responsabilizado por quatro homicídios triplamente qualificados envolvendo violência arbitrária com coautoria de crime e concurso material (GUANABARA, 1965, p.354).

Em nível de esclarecimento, os quatro qualificantes de homicídio apontados pelo Ministério Público dizem respeito a motivação torpe (compreendida como abjeta, indigna), motivação fútil (compreendida como banal), com emprego de meios cruéis e recursos que dificultem ou impossibilitem a defesa da vítima. Todavia, a sentença de pronúncia excluiu, em todos os casos, o qualificante de motivação fútil. Quanto ao homicídio de 
Djalma Alves da Silva no SRM, os dois qualificantes denunciados compreendiam motivação fútil e recursos que dificultaram a defesa da vítima, mas a motivação fútil foi alterada para motivação torpe na sentença pronunciada. O abuso de poder referido na denúncia diz respeito a submeter pessoa sob sua guarda a constrangimento não autorizado em lei e efetuar quaisquer diligências com abuso de poder. O conceito de coautoria é autoevidente, e concurso material diz respeito à possibilidade de aplicar penas cumulativas para crimes que decorram de mais de uma ação ou omissão do réu. Na sentença, o abuso de poder foi substituído por violência arbitrária, ou seja, prática de violência pelo réu no exercício de suas funções. A tipificação de concurso material e sua disposição ao longo do Código Penal foram alteradas em 1984. Atualmente o concurso material se apresenta no art. 69, e não mais no art. 51. A questão da coautoria também foi brevemente alterada e deslocada, se apresentando no art. 29, e não mais no art. 25. E o abuso de poder foi eliminado do Código Penal em 2019.

Para além das arbitrariedades julgadas, uma quinta viagem confessada pelos implicados à imprensa não foi arrolada na ação penal. Esta teria sido realizada em 4 de dezembro de 1962 com a participação de José Mota, Pedro Saturnino dos Santos, Nilton Gonçalves da Silva, Anísio Magalhães da Costa e Martinho José Graciano. Teriam sido executados seis "mendigos" não identificados no rio Guandu (ÚLTIMA HORA, 12/02/1963). Desta forma, o número total e rastreável de vítimas fatais na chamada "Operação matamendigos" é de vinte indivíduos, somando-se as cinco viagens e a morte de Djalma Alves da Silva nas dependências do SRM.

\section{Uma síntese das arbitrariedades e algumas considerações}

Enquanto acontecimento histórico, o objeto de nosso interesse pode ser compreendido como um conjunto de arbitrariedades e execuções perpetradas por agentes do SRM guanabarino contra "mendigos" entre 1962 e 1963. Após violentadas, as vítimas eram usualmente atiradas nos rios Guandu ou da Guarda 
(GUANABARA, 1963; 1965). Essa síntese geral é convergente com o que trazem outros trabalhos (ANTONIO, 2019; 2020; FISCHER, 2008; FREITAS, 2018; MONTEIRO, 2020; MORTON, 2015; MOTTA, 2001), mas as narrativas advindas do Poder Público e complementadas pela cobertura da imprensa nos permitem traçar um quadro geral do conjunto de episódios que compõem a "Operação mata-mendigos" (Tabela 2) e dos crimes identificados pelo juiz prolator (Tabela 3) que usualmente são negligenciados por narrativas sintéticas e tangenciais a outras problemáticas de pesquisa. ${ }^{7}$

Podemos compreender a "Chacina do rio da Guarda" como momento fundador do caso na esfera pública, muito embora esta não tenha sido a primeira viagem de extermínio. Desse modo, distinguimos um episódio pontual e fundacional ("Chacina do rio da Guarda"), um conjunto discreto de práticas de extermínio (“Operação mata-mendigos”) e um conjunto amplo e difuso de práticas de extorsão, deportação e abandono de pessoas socialmente vulneráveis por agentes de segurança pública.

Nossa opção pelo termo nativo "mendigo" visa explicitar a construção do indivíduo como contraventor segundo o ordenamento jurídico da época, uma particularidade que não consegue ser devidamente sinalizada pelos termos "morador de rua" ou "pessoa em situação de rua". Observe-se que a contravenção de mendicância fez parte da Lei de Contravenções Penais até 2009, e o agenciamento das violências aqui apresentadas por quadros da segurança pública reforça aspectos já adereçados por Michel Misse (1999, p.48) acerca da sujeição criminal, ou seja, da expectativa de que determinadas categorias de indivíduos "acusáveis" incorram em condutas atentatórias aos valores dominantes, sendo "legítimas" as diversas formas de violência legal e extralegal em sua contenção. Ao mesmo tempo, o "mendigo" constituiria uma espécie de sujeito limiar, o que teria facilitado a ressignificação do termo pelo jornal Ultima Hora quando da eclosão de denúncias sobre o caso, deixando de

\footnotetext{
${ }^{7}$ A Tabela 2 e a Tabela 3 apenas sintetizam dados já apresentados ao longo do texto, durante a análise da sentença de pronúncia. Optamos pelas duas formas de apresentação dos dados para facilitar a compreensão do leitor.
} 
figurar como um ente daninho e se tornando digno de piedade (ANTONIO, 2019, p.87).

Ademais, o problema da mendicância aqui abordado se desenvolve num contexto mais amplo de expansão demográfica desordenada e acentuação das desigualdades sociais. Ao longo das décadas de 1950 e 1960, a cidade do Rio de Janeiro sofreu um intenso inchaço populacional, sobretudo em áreas periféricas. A população favelada dobrou nesse período, passando de 169.305 para 335.063 habitantes, chegando a representar cerca de $10 \%$ da população carioca. Tal inchaço deriva de grandes ondas migratórias, oriundas de diversas regiões do país, em busca de melhores condições de vida; mas a disparidade entre a oferta e a procura de empregos fez com que houvesse um aumento dos bolsões de pobreza urbana, fixando parte desses grupos populacionais em bairros e áreas periféricas da cidade ou municípios próximos (especialmente na Baixada Fluminense) (MOTTA, 2001, p.108-109; PERLMAN, 1977, p.92-95).

Conforme abordado, as viagens de deportação de "mendigos" para seus supostos estados de origem também caracterizam crimes, densamente abordados durante o inquérito parlamentar e reconhecidos como prática ilegal na matéria de direito da sentença (GUANABARA, 1965, p.352). Todavia, é inconclusivo se essas viagens se tornaram objeto de ação penal ou sanção administrativa contra quaisquer envolvidos.

Tabela 2 - Relação de arbitrariedades julgadas e confessadas

\begin{tabular}{|c|c|c|}
\hline Viagem & Perpetradores & Vítimas \\
\hline $\begin{array}{c}\mathbf{1}^{\text {a }} \text { Viagem } \\
15 / 10 / 1962 \\
\text { Rio Guandu }\end{array}$ & $\begin{array}{l}\text { José Mota } \\
\text { Pedro Saturnino dos Santos } \\
\text { Nilton Gonçalves da Silva } \\
\text { Anísio Magalhães da Costa }\end{array}$ & $\begin{array}{l}\text { Elias Marcondes (executado) } \\
\text { Expedito Jesus Vieira (executado) } \\
\text { José dos Santos (executado) }\end{array}$ \\
\hline $\begin{array}{l}2^{\text {a Viagem }} \\
19 / 10 / 1962 \\
\text { Rio Guandu }\end{array}$ & $\begin{array}{l}\text { José Mota } \\
\text { Pedro Saturnino dos Santos } \\
\text { Nilton Gonçalves da Silva } \\
\text { Anísio Magalhães da Costa } \\
\text { Martinho José Graciano }\end{array}$ & $\begin{array}{l}\text { José Vital da Silva (executado) } \\
\text { Antônio Maia da Conceição (executado) } \\
\text { Sebastião Ribeiro Ambrósio (executado) } \\
\text { Ari Loiola Barata (executado) } \\
\text { João Goulart (sobrevivente, deportado) } \\
\text { Agenor José Gonçalves } \\
\text { (sobrevivente, deportado, anônimo na ação } \\
\text { penal) } \\
\text { Vitório de Souza } \\
\text { (sobrevivente, deportado, anônimo na ação } \\
\text { penal) }\end{array}$ \\
\hline
\end{tabular}




\begin{tabular}{|c|c|c|}
\hline & & $\begin{array}{l}\text { Elizeu José Gonçalves } \\
\text { (sobrevivente, deportado, anônimo na ação } \\
\text { penal) }\end{array}$ \\
\hline $\begin{array}{l}3^{\text {a Viagem }} \\
07 / 01 / 1963 \\
\text { Rio Guandu }\end{array}$ & $\begin{array}{l}\text { José Mota } \\
\text { Pedro Saturnino dos Santos } \\
\text { Nilton Gonçalves da Silva } \\
\text { Anísio Magalhães da Costa }\end{array}$ & $\begin{array}{l}\text { Olga Pereira dos Santos (executada) } \\
\text { Pedro Francisco Cachoeiro } \\
\text { (sobrevivente, tentativa de homicídio) } \\
\text { Marcionília Catarina (sobrevivente - } \\
\text { deportada) } \\
\text { Maria Luiza do Socôrro } \\
\text { (sobrevivente, violência sexual) }\end{array}$ \\
\hline $\begin{array}{c}\mathbf{4}^{\text {a }} \text { Viagem } \\
17 / 01 / 1963 \\
\text { Rio da Guarda }\end{array}$ & $\begin{array}{l}\text { José Mota } \\
\text { Pedro Saturnino dos Santos } \\
\text { Nilton Gonçalves da Silva } \\
\text { Mário Teixeira }\end{array}$ & $\begin{array}{l}\text { José de tal (executado) } \\
\text { Milton Rodrigues Barbosa (executado) } \\
\text { Geraldo Pereira (executado) } \\
\text { Eunice Marques Evangelista (executada) } \\
\text { Zuleica de tal (executada) } \\
\text { Olindina Alves Japiassu } \\
\text { (sobrevivente, tentativa de homicídio) }\end{array}$ \\
\hline $\begin{array}{c}\text { Morte por } \\
\text { espancamento } \\
\text { Setembro/1962 } \\
\text { Dependências } \\
\text { do SRM } \\
\end{array}$ & $\begin{array}{l}\text { José Mota } \\
\text { Nilton Gonçalves da Silva } \\
\text { Alcino Pinto Nunes }\end{array}$ & Djalma Alves da Silva (executado) \\
\hline $\begin{array}{c}\mathbf{5}^{\mathbf{a}} \text { Viagem } \\
\text { (Não arrolada } \\
\text { na ação penal) } \\
04 / 12 / 1962 \\
\text { Rio Guandu }\end{array}$ & $\begin{array}{l}\text { José Mota } \\
\text { Pedro Saturnino dos Santos } \\
\text { Nilton Gonçalves da Silva } \\
\text { Anísio Magalhães da Costa } \\
\text { Martinho José Graciano }\end{array}$ & Seis vítimas não identificadas (executadas) \\
\hline
\end{tabular}


Tabela 3 - Tipificação penal para os crimes conforme sentença de pronúncia

\begin{tabular}{|c|c|}
\hline Implicado & Fundamentação a partir do Código Penal vigente \\
\hline $\begin{array}{l}\text { Alcino } \\
\text { Pinto } \\
\text { Nunes }\end{array}$ & $\begin{array}{l}\text { Art. } 121, \S 2^{\circ} \text {, ns. I, III e IV - } 13 \text { incidências de homicídio triplamente } \\
\text { qualificado } \\
\text { Art. } 121, \S 2^{\circ} \text {, ns. I e IV - } 1 \text { incidência de homicídio duplamente qualificado } \\
\text { Art. } 322 \text {, combinado com Art. } 25 \text { e Art. } 51 \text { - } 14 \text { incidências de violência arbitrária } \\
\text { com coautoria de crime e concurso material } \\
\text { Art. } 312 \text { - Peculato }\end{array}$ \\
\hline $\begin{array}{l}\text { o } \\
\text { lhães } \\
\text { sta }\end{array}$ & $\begin{array}{l}\text { Art. } 121, \S 2^{\circ} \text {, ns. I, III e IV - } 8 \text { incidências de homicídio triplamente qualificado } \\
\text { Art. } 322 \text {, combinado com Art. } 25 \text { e Art. } 51 \text { - } 8 \text { incidências de violência arbitrária } \\
\text { com coautoria de crime e concurso material }\end{array}$ \\
\hline Jos & $\begin{array}{l}\text { Art. } 121, \S 2^{\circ} \text {, ns. I, III e IV - } 13 \text { incidências de homicídio triplamente } \\
\text { qualificado } \\
\text { Art. } 121, \S 2^{\circ} \text {, ns. I e IV - } 1 \text { incidência de homicídio duplamente qualificado } \\
\text { Art. } 322 \text {, combinado com Art. } 25 \text { e Art. } 51 \text { - } 14 \text { incidências de violência arbitrária } \\
\text { com coautoria de crime e concurso material }\end{array}$ \\
\hline $\begin{array}{l}\text { Mário } \\
\text { Teixeira }\end{array}$ & $\begin{array}{l}\text { Art. } 121, \S 2^{\circ} \text {, ns. I, III e IV - } 5 \text { incidências de homicídio triplamente qualificado } \\
\text { Art. } 322 \text {, combinado com Art. } 25 \text { e Art. } 51 \text { - } 5 \text { incidências de violência arbitrária } \\
\text { com coautoria de crime e concurso material }\end{array}$ \\
\hline $\begin{array}{l}\text { Martinho } \\
\text { José } \\
\text { Graciano }\end{array}$ & $\begin{array}{l}\text { Art. } 121, \S 2^{\circ} \text {, ns. I, III e IV - } 4 \text { incidências de homicídio triplamente qualificado } \\
\text { Art. } 322 \text {, combinado com Art. } 25 \text { e Art. } 51 \text { - } 4 \text { incidências de violência arbitrária } \\
\text { com coautoria de crime e concurso material }\end{array}$ \\
\hline $\begin{array}{l}\text { Nilton } \\
\text { Gonçalves } \\
\text { da Silva }\end{array}$ & $\begin{array}{l}\text { Art. } 121, \S 2^{\circ} \text {, ns. I, III e IV - } 12 \text { incidências de homicídio triplamente } \\
\text { qualificado } \\
\text { Art. } 121, \S 2^{\circ} \text {, ns. I e IV - } 1 \text { incidência de homicídio duplamente qualificado } \\
\text { Art. 322, combinado com Art. } 25 \text { e Art. } 51 \text { - } 13 \text { incidências de violência arbitrária } \\
\text { com coautoria de crime e concurso material }\end{array}$ \\
\hline $\begin{array}{l}\text { Pedro } \\
\text { Saturnin } \\
\text { dos Sant }\end{array}$ & $\begin{array}{l}\text { Art. } 121, \S 2^{\circ} \text {, ns. I, III e IV - } 13 \text { incidências de homicídio triplamente } \\
\text { qualificado } \\
\text { Art. 322, combinado com Art. } 25 \text { e Art. } 51 \text { - } 13 \text { incidências de violência arbitrária } \\
\text { com coautoria de crime e concurso material }\end{array}$ \\
\hline
\end{tabular}

Fonte: GUANABARA, 1965.

A apresentação dos crimes atribuídos a cada perpetrador durante $\mathrm{o}$ inquérito criminal, a partir do noticiário do Ultima Hora (Cf. ANTONIO, 2019, p.95), apresenta equívocos notáveis se comparados às denúncias remetidas pelo Ministério Público ou à sentença de pronúncia. Isso nos mostra que, embora a análise seriada dos registros de imprensa permita o diagnóstico de determinados equívocos pelo cruzamento das fontes e exclusão de incoerências, alguns ruídos podem atravessar o crivo investigativo.

Por outro lado, se as fontes aqui analisadas nos permitem recuperar informações ora negligenciadas, elas também deixam de lado algumas questões necessárias para a plena compreensão de como o caso se desenvolveu. Veja-se que essas fontes não detalham as reconstituições dos crimes ou a coexistência 
de diversos inquéritos sobre o caso (ao todo: um inquérito criminal, um parlamentar e dois administrativos), seja pelo fato de serem procedimentos subentendidos ou pela necessidade de síntese imposta aos documentos. Tanto a sentença de pronúncia quanto o parecer do relator da CPI são partes discretas de uma massa documental mais ampla contida em autos processuais, eventualmente trazendo remissões a outros documentos no mesmo processo.

O momento de produção da fonte também impossibilita a extração de informações sobre acontecimentos posteriores, tão necessárias para a compreensão do caso. A partir de fontes de imprensa, Antonio (2019, p.94-95) atenta que José Mota faleceu aguardando julgamento em abril de 1964; Pedro Saturnino dos Santos foi condenado a 316 anos de prisão em 1967; Nilton Gonçalves da Silva foi condenado a 317 anos de prisão e 1 ano de serviços em colônia agrícola em 1968; Anísio Magalhães da Costa foi condenado a 202 anos, 9 meses e 10 dias de prisão em 1969; Mário Teixeira foi condenado a 10 anos de prisão em 1970; e Martinho José Graciano foi condenado a 91 anos de prisão também em 1970; todos em júri popular devido à tipificação dos crimes. Alcino Pinto Nunes conseguiu liberdade provisória para aguardar julgamento em 1974. O ex-chefe do SRM faleceu no ano seguinte, conforme noticiado pelo jornal O Pasquim (1 $\left.1^{\circ}-07 / 08 / 1975\right)$. Em vista da sentença de pronúncia e da data de falecimento, notamos que os crimes ainda não estavam prescritos quando de sua morte. Cumpre-nos esclarecer que uma sentença de pronúncia não põe fim a um julgamento ou condena os réus, mas decide que há indícios de crime doloso contra a vida e orienta a decisão do júri popular.

Freitas (2018, p.82-83) aborda mudanças nas relações entre Poder Público e pessoas em situação de rua decorrentes de pressões criadas pela “Operação mata-mendigos”. Em 1966, um novo “Centro de Recuperação de Mendigos" seria coordenado pela assistente social Yeda Benzecry, em substituição ao extinto SRM.

Um dos objetivos do serviço recém criado era o recolhimento de mendigos que se encontram nas ruas ou em outros órgãos. Ou mesmo a partir da procura espontânea destes. Apreendese que o objetivo era recolher para recuperar e integrar essas 
pessoas à sociedade, conforme texto de Benzecry. Funcionava a partir de duas unidades: uma em Bonsucesso e outra em Campo Grande. Na tese, Benzecry menciona que os mendigos não participam do desenvolvimento social do país, por isso precisam ser recuperados (FREITAS, 2018, p.82).

A rememoração do morticínio através do longa-metragem Topografia de um desnudo sustenta um esquecimento do caso a partir do golpe civil-militar de 1964, mas a presente análise nos mostra que os perpetradores foram julgados e o inquérito parlamentar foi inconclusivo e incapaz de produzir provas contra autoridades superiores. A remessa dos autos da CPI ao judiciário fora postergada por manobra do deputado Raul Brunini (UDN), conforme noticiado pelo Correio da Manhã (16/11/1964). Entretanto, o Poder Judiciário chegou a apreciar os autos durante o julgamento de Nilton Gonçalves da Silva, conforme o jornal O Globo (29/09/1968). Com ou sem apreciação dos documentos produzidos pelo inquérito parlamentar, nossa análise do parecer deixa evidente que pouco ou nada seria adicionado à ação penal.

Segundo Morton (2015, p.305, tradução livre):

O extermínio entrou para o folclore carioca. É amplamente acreditado que a polícia estava limpando tudo para a visita do presidente Eisenhower, que de fato compareceu em 1960, ou para a visita de Elizabeth II, que compareceu em 1968. Alega-se o uso do rio Guandu, fonte de $80 \%$ do abastecimento de água do Rio de Janeiro, ao invés do rio da Guarda. E numa nota tipicamente carioca, diz-se que os mendigos sobreviventes foram fotografados nas avenidas do centro, exercendo seu ofício enquanto usavam coletes salvavidas.

O peso dos discursos infundados é tão notável que atinge até mesmo seus críticos. Apesar de apontar algumas inverdades em torno do caso, Morton (2015, p.305) negligencia o amplo uso do rio Guandu durante as arbitrariedades e também replica discursos sobre a impunidade de mandantes e perpetradores, $o$ que conflita com as fontes sincrônicas aqui analisadas e com os registros de imprensa. Diante de tantas disputas pelo estabelecimento e difusão de memórias sobre a "Operação mata-mendigos", nossa análise de duas fontes de acesso 
mais dificultoso ou negligenciado, gestadas pelo Poder Público, auxiliam na compreensão do caso e das narrativas que o orbitam.

\section{Referências}

ANTONIO, Mariana Dias. A "Operação mata-mendigos" (Rio de Janeiro, 1962-1963) às margens de alguns livros. Simbiótica. Vitória, v. 7, n. 2, p. 163 180, 2020. Disponível em: https://periodicos.ufes.br/simbiotica/article/view/32598/21536.

ANTONIO, Mariana Dias. A “Operação mata-mendigos" e o jornal Ultima Hora (Rio de Janeiro, 1961-1969). Vozes, Pretérito \& Devir. Teresina, v. 9, n. 1, p. 85-105, 2019. Disponível em: revistavozes.uespi.br/ojs/index.php/revistavozes/article/view/203.

CORREIO DA MANHÃ. Correio da Manhã, Rio de Janeiro, p. 3, 06 nov. 1964. Disponível em: http://memoria.bn.br/DocReader/089842 07/57194.

FISCHER, Brodwyn. A Poverty of Rights. Stanford: Stanford University Press, 2008.

FREITAS, Renata Martins de. População em situação de rua e a questão social no Rio de Janeiro. 2018. Dissertação (Mestrado em Ciências Sociais), Universidade Federal Rural do Rio de Janeiro, Seropédica, 2018, 174p.

GUANABARA. Assembléia Legislativa. Comissão Parlamentar de Inquérito para investigar e apurar os fatos relacionados com a matança de mendigos no rio da Guarda e desaparecimento de cidadãos da Invernada de Olaria e demais estabelecimentos policiais do estado. Parecer do Relator. II ${ }^{a}$ parte: deportação e matança de mendigos, 1963 [Arquivo da Assembleia Legislativa do Estado do Rio de Janeiro. Fundo ALEG. Dossiê 2000-2.05, Pasta P1065].

GUANABARA. Tribunal de Justiça da Guanabara. Recurso no 5.977. Acórdão. Relator: Roberto Medeiros. Guanabara, 03 dez. 1964; Sentença. Prolator: Roberto Talavera Bruce. Guanabara, 18 jul. 1963. Revista Forense, Guanabara, v. 212, p. 333-355, 1965.

MISSE, Michel. Malandros, marginais e vagabundos e a acumulação social da violência no Rio de Janeiro. 1999. Tese (Doutorado em Ciências Humanas: Sociologia), Instituto Universitário de Pesquisas do Rio de Janeiro, Rio de Janeiro, 1999. 413p.

MONTEIRO, Karla. Samuel Wainer. São Paulo: Companhia das Letras, 2020.

MORTON, Orde. Rio. Victoria: FriesenPress, 2015. 
MOTTA, Marly Silva da. Rio de Janeiro. Rio de Janeiro: Editora FGV, 2001.

O GLOBO. O Globo (Matutino), Rio de Janeiro, p. 12, 29 set. 1968.

O PASQUIM. O Pasquim, Rio de Janeiro, p. 27, $\mathrm{n}^{\circ}$ 318, $1^{\circ}$ a 07 ago. 1975.

PERLMAN, Janice. O mito da marginalidade. trad. Waldívia Marchiori Portinho. Rio de Janeiro: Paz e Terra, 1977.

ULTIMA HORA. Ultima Hora (Vespertino), Rio de Janeiro, p. 9, 05 fev. 1963.

ULTIMA HORA. Ultima Hora (Vespertino), Rio de Janeiro, p. 9, 12 fev. 1963.

ULTIMA HORA. Ultima Hora (Vespertino), Rio de Janeiro, p. 7, 14 fev. 1963.

ULTIMA HORA. Ultima Hora (Vespertino), Rio de Janeiro, p. 7, $1^{\circ}$ mar. 1963.

ULTIMA HORA. Ultima Hora (Vespertino), Rio de Janeiro, p. 9, 17 abr. 1963.

ULTIMA HORA. Ultima Hora (Vespertino), Rio de Janeiro, p. 7, 08 ago. 1963.

ULTIMA HORA. Ultima Hora (Vespertino), Rio de Janeiro, p. 7, 19 set. 1963.

ULTIMA HORA. Ultima Hora (Vespertino), Rio de Janeiro, p. 8, 06 nov. 1963.

Recebido em: 02 de novembro de 2020

Aceito em: 08 de outubro de 2021 